\title{
Analysis of Electricity Consumption in Poland Using Prediction Models and Neural Networks
}

\author{
Monika Zielińska-Sitkiewicz ${ }^{1, *}$, Mariola Chrzanowska ${ }^{1} \mathbb{D}$, Konrad Furmańczyk $^{2}$ ad and $_{\text {Kacper Paczutkowski }}{ }^{2}$ \\ 1 Department of Statistics and Econometrics, Institute of Economics and Finance, \\ Warsaw University of Life Sciences, 02-787 Warsaw, Poland; mariola_chrzanowska@sggw.edu.pl \\ 2 Department of Applied Mathematics, Institute of Information Technology, Warsaw University of Life Sciences, \\ 02-787 Warsaw, Poland; konrad_furmanczyk@sggw.edu.pl (K.F.); kacper_paczutkowski@sggw.edu.pl (K.P.) \\ * Correspondence: monika_zielinska_sitkiewicz@sggw.edu.pl
}

Citation: Zielińska-Sitkiewicz, M.; Chrzanowska, M.; Furmańczyk, K.; Paczutkowski, K. Analysis of Electricity Consumption in Poland Using Prediction Models and Neural Networks. Energies 2021, 14, 6619. https://doi.org/10.3390/en14206619

Academic Editors: Agata Balińska and François Vallée

Received: 24 August 2021

Accepted: 3 October 2021

Published: 14 October 2021

Publisher's Note: MDPI stays neutral with regard to jurisdictional claims in published maps and institutional affiliations.

Copyright: (c) 2021 by the authors. Licensee MDPI, Basel, Switzerland. This article is an open access article distributed under the terms and conditions of the Creative Commons Attribution (CC BY) license (https:/ / creativecommons.org/licenses/by/ $4.0 /)$.

\begin{abstract}
The challenges of the modern world require transformations in the energy market towards the possible reduction of consumption and greater use of renewable sources. The conducted research of consumers of this market confirms that the behaviour in the field of increased use of renewable energy is burdened with cognitive errors and motivational factors, which makes it difficult to conduct quantitative research. Electricity demand forecasting can be modelled using selected quantitative methods. In this way, not so much the behaviour, but the result of the consumer's behaviour is predicted. The research presented in the article has been divided into two parts. The aim of the first one is to study the prospects of a greater share of renewable sources in obtaining energy in Poland, based on the attitudes and opinions of consumers on the retail energy market, legal regulations and the energy balance. The aim of the second part is to build forecasts of daily, weekly, monthly and quarterly electricity consumption in Poland, including the prediction of the RES share, using selected machine and deep learning methods. The analyses used the time series of daily electricity consumption in Poland from 2015-2021; the ENTSO-E data was obtained from the cire.pl website. Depending on the adopted forecast horizon, the forecasting method with the lowest MAPE error was exponential smoothing, SARIMA and NNETAR. An evolution of energy consumers' attitudes towards pro-ecological and pro-social sensitivity and understanding of the importance of RES for the economy was also observed.
\end{abstract}

Keywords: energy consumer research; energy consumption forecasting; RES; machine and deep learning

\section{Introduction}

Electricity in the modern market economy is one of the basic factors guaranteeing the socio-economic development and quality of life of the society. It facilitates production, transport, trade, communication and is present in practically all spheres of human life. For the modern consumer, it is an essential element of life, facilitating its functioning in the economy and society, and creates appropriate conditions for work and rest.

Electricity itself is subject to market exchange, demanded by all consumers. In a free market economy, the consumer is an independent entity on the electricity market. On the Polish retail energy market, electricity consumers can be divided into two main groups:

Households, i.e., all customers buying energy for communal and living purposes.

Other consumers, who are not households, buy energy for the needs of their economic activity, i.e., National Railway, industrial plants, offices, hotels, shopping centres, institutions, etc. [1].

Based on the data from the Energy Regulatory Office [2], Table 1 presents the structure of end users (in million units) of the retail energy market in Poland for 2015-2019. The presented data for various tariff groups show that the number of energy consumers has been systematically growing by an average of about $1 \%$ from year to year. 
Table 1. Final consumers of electricity in Poland according to tariffs (in million).

\begin{tabular}{ccccc}
\hline Year & $\begin{array}{c}\text { Total End } \\
\text { Customers }\end{array}$ & $\begin{array}{c}\text { End Customers } \\
\text { from Tariff } \\
\text { Groups G }\end{array}$ & $\begin{array}{c}\text { End Customers from } \\
\text { Tariff Groups G } \\
\text { (Only Households) }\end{array}$ & $\begin{array}{c}\text { End Customers } \\
\text { from Tariff } \\
\text { Groups A B C }\end{array}$ \\
\hline 2015 & 17.168 & 15.40 & 14.50 & 1.768 \\
2016 & 17.363 & 15.61 & 14.63 & 1.753 \\
2017 & 17.503 & 15.80 & 14.90 & 1.703 \\
2018 & 17.714 & 16.00 & 15.10 & 1.714 \\
2019 & 17.935 & 16.20 & 15.10 & 1.735 \\
\hline
\end{tabular}

A-tariff for companies supplied from high voltage power grids, B-tariff for companies supplied by medium voltage power grids, C-tariff for companies supplied from low voltage power grids, G-tariff for urban and rural households, houses of collective housing, e.g., dormitories, summer houses and common rooms in blocks of flats.

Since 2000, domestic electricity consumption has increased. Between 2000 and 2019, the increase in electricity supplies to end users was $34.5 \%$ (i.e., by approx. $34.65 \mathrm{TWh}$ ), but for the period 2015-2019 the increase in supplies was only 6.8\% (i.e., approx. $8.64 \mathrm{TWh}$ ). Electricity supplies to households and small farms remained fairly stable in 2000-2019. However, their share in total deliveries systematically decreased from $25.66 \%$ in 2000 to $22.65 \%$ in 2019 (Figure 1).

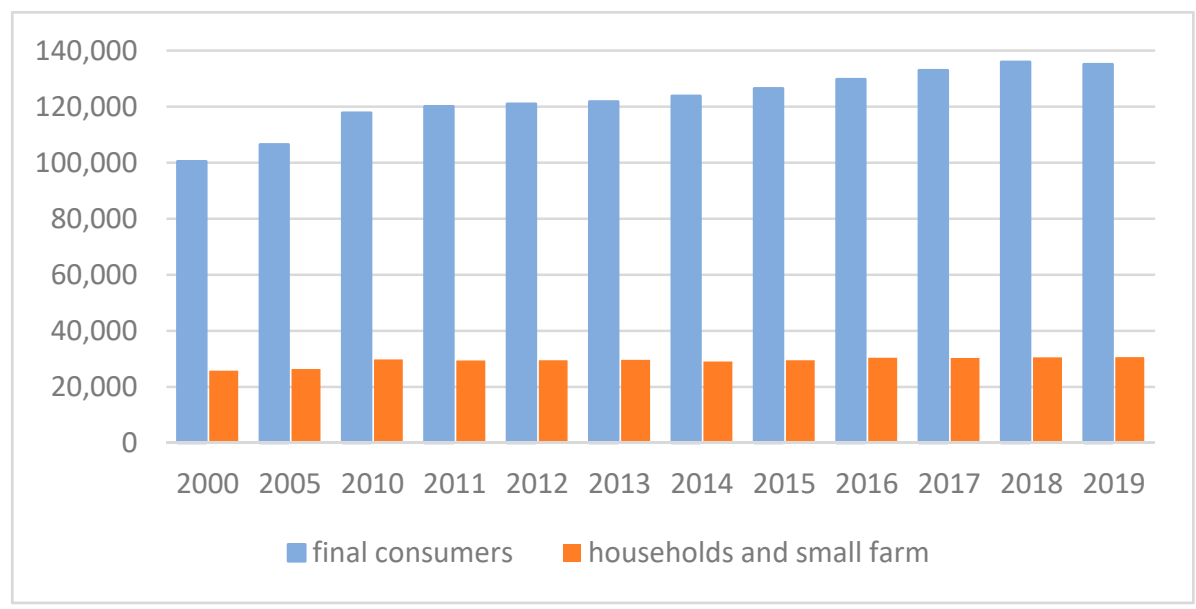

Figure 1. The supply of electricity to final consumers in Poland (in GWh).

When analysing the data of Poland's energy balance for the years 2000-2019 [3], it can be seen that the peak of the volume of domestic electricity production was achieved in 2017 (approx. 165.9 TWh). In 2018-2019, there was a slow decline in production volume, which was the result of shutting down some generating units that did not meet EU emission standards. The effect of high consumption of electricity, not covered by domestic production, was an increase in its import. This is a permanent tendency, mainly due to the loss of competitiveness of the Polish offer on the open electricity market. Producing electricity from coal is simply expensive. Since 2014, Poland has increased the scale of energy imports, among others, thanks to the development of cross-border connections. In 2019 , electricity consumption for the entire year was $174,612 \mathrm{GWh}$, i.e., less by $0.6 \%$ than in the previous year, with a total production of 163,989 GWh (a decrease by 3.6\%). Imports covered the production shortage in the country. For 2019, the negative foreign exchange balance amounted to $10,623.7 \mathrm{GWh}$, i.e., more than in the previous year by $4906.0 \mathrm{GWh}$ (Figure 2). 


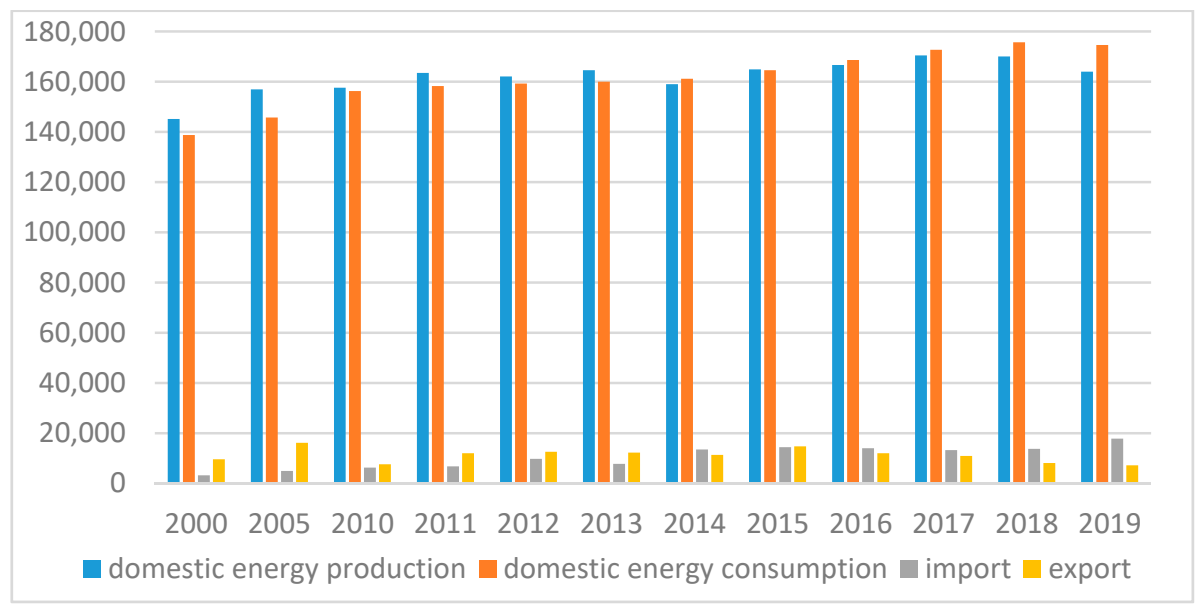

Figure 2. Poland's energy balance for 2000-2019 (in GWh).

In 2020, the COVID-19 pandemic had a significant impact on the functioning of the energy market in Poland. In the first period of the pandemic, the demand for electricity decreased. Energy production was the lowest in a decade at $157.7 \mathrm{TWh}$, and energy imports increased to $13.3 \mathrm{TWh}$, which accounted for about $7.8 \%$ of energy consumption. Moreover, for the first time ever, the share of energy from coal was less than $70 \%$, i.e., it had dropped to around $65 \%$. This was due to the construction of new gas-fired units and renewable sources (RES). In 2020 , over $24 \%$ of capacity ( 28 TWh) was constituted by renewable energy sources, but the share of RES was still lower than the level meeting the EU obligations. The production of energy from photovoltaics grew the most dynamically thanks to the appropriate support systems, and in 2020, it was 3.5 times higher than in 2019 (Figure 3) [4].
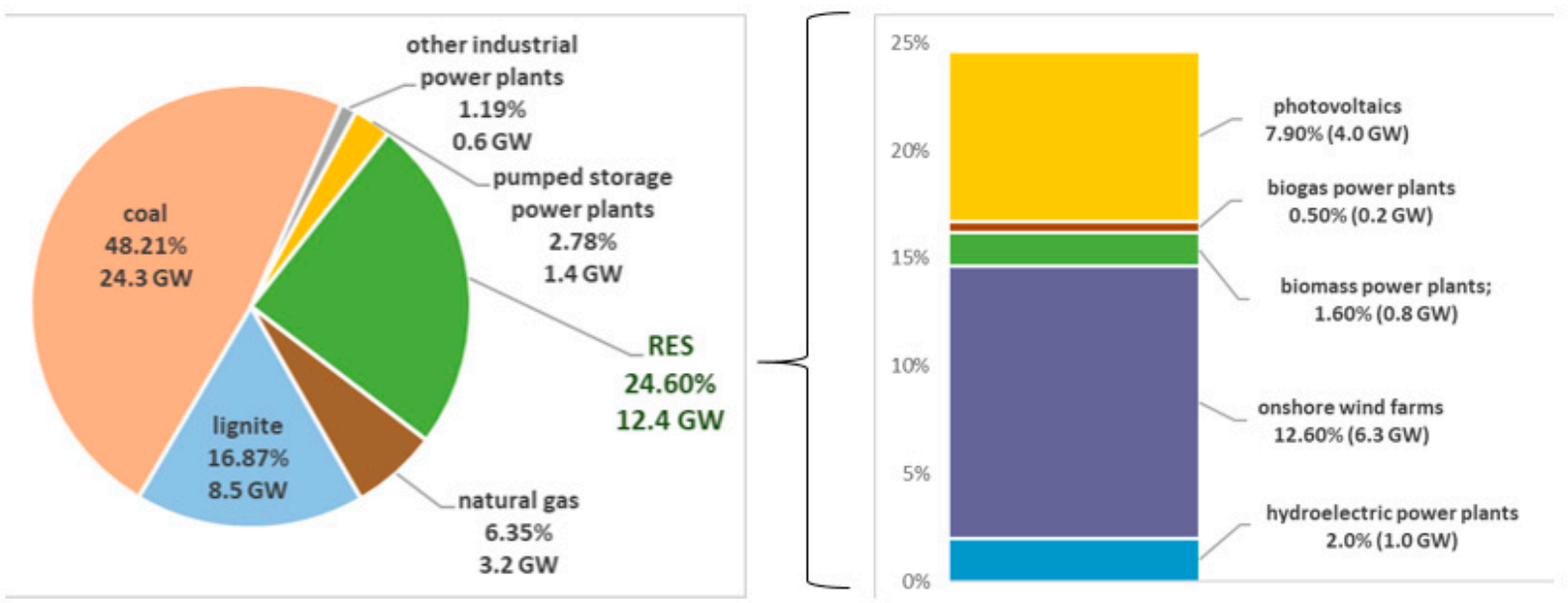

Figure 3. Generation capacity in Poland in 2020 (in GW).

In summary, the acceleration of RES development in Poland in 2020 was the result of both the commissioning of large-scale onshore solar and wind power plants and the rapidly growing number of so-called prosumers, i.e., conscious consumers involved in ecological energy production.

Renewable energy sources are becoming more and more popular in Europe. Scandinavian countries are the leaders in the European RES sector. For example, in Norway, as much as $97 \%$ of the national energy mix in 2021 is based on hydropower, and according to the announcements of government advisory institutes in Oslo, Norway has a chance to abandon fossil fuels by 2050. Sweden uses the potential of wind farms, hydropower plants, but also biomass. Already in 2015, it was reported that as much as $99 \%$ of Swedish 
waste is used for energy production. For comparison, in Poland this ratio is currently only about $6 \%$. In 2019, Denmark declared that as much as $47 \%$ of the national mix was based on energy generated by windmills. In turn, Finland, increasing its investments in biogas, in 2020, achieved a 38.7\% share of renewable energy in gross final energy consumption. Moreover, Finland, which had a great influence on the policy of the Baltic states, contributed to changes in the approach to the energy mix in Estonia and Latvia. Estonia already in 2019 could boast of a 30 percent share of renewable energy in gross final energy consumption (the 2020 target was 25\%). In 2020, the Latvian national RES sector was third in terms of the share of renewable energy in the entire European Union with a result of $35.2 \%$. The government in Riga based its energy policy on firewood, which facilitated the fight against GHG emissions, i.e., greenhouse gases. Ultimately, Latvia wants to base its energy policy on wind farms and is implementing investments in this direction. While the north of Europe is distinguished by dynamic investments in RES, other European countries are slightly behind in this respect [5,6]. In the case of Polish investments in RES, according to S. Jabłoński-President of the Management Board of Respect Energy, the domestic market must focus on an innovative approach to the sector and mobilization of the customers themselves. It is consumers who can most contribute to the development of the RES industry in Poland, and for them, green energy can become an integral part of life style [7].

When considering the market choices of end consumers of electricity, it is reasonable to refer to selected areas of economic research. The theory of classical economics indicates that individuals make economic decisions on the basis of complete information and act rationally, i.e., they are guided by profit maximization (producers) and expected utility (consumers) maximization at given inputs [8]. In turn, the most accepted contemporary definition of economics was formulated in 1932 by Lionel Ch. Robbins arguing that economics is a science that studies human behaviour as a relationship between goals and limited means that may have alternative applications [9] (p. 16). The first part of this definition suggests the importance of studying human behaviour, and this element is emphasized by many contemporary researchers who define economics as a science [10]. Additionally, it is worth mentioning that already Adam Smith, in the work The Theory of Moral Sentiments published in 1853, noted that man is often guided by higher feelings when it comes to the development of the community and its happiness [11] (p. 126) as well as altruism and concern when one should take care of one's own happiness, but also the happiness of the family or the country [11] (p. 353). Hence, the core of economic theory must be the theory of human behaviour, because it is the species of homo sapiens that is the creator of the econosphere, i.e., the global economic system consisting of billions of people and organizations that multiply the achievements of humanity [12] (p. 115).

Therefore, it can be assumed that the basic subject of economics as a scientific discipline is man and his behaviour related to broadly understood economic activities [13]. Observations made in the field of behavioural economics disturbed two pillars on which the concept of homo œconomicus was based: self-interest and rational choice. Behavioural economics combined the theory of classical and neoclassical economics with psychological models of human behaviour verified experimentally, especially in the field of motivation research [14].

The importance of behavioural economics in contemporary economic thought is confirmed by the winners of two Nobel Prizes. The first was awarded in 2002 to Daniel Kahneman [15] and Vernon L. Smith [16] in the fields of economic psychology and experimental economics, and the second in 2017 to Richard H. Thaler $[17,18]$ for combining the analysis of the process of making economic decisions with psychological research. Thaler showed that people do not always act rationally, have problems with self-control, and the behaviour of individuals is influenced by social preferences [19]. These theories are confirmed by, for example, consumer boycotts, which can also be treated as one of the manifestations of building a civil society. Their motivations are very different. An example of political motivation was the complete boycott of Japanese airlines in China in 2016, 
triggered by the dispute between Japan and China over access to the Senkaku islands, to oil fields. Ideological reasons in 2014 decided to boycott the Polish Ciech beer for homophobic statements of the brand owner. However, most often consumers are guided by ethical and ecological reasons, an example of which were: a very severe boycott of BP in 2010 in retaliation for the oil spill in the Gulf of Mexico, an effective boycott of Doritos in Poland in 2018 , which resulted in the removal of palm oil from the composition of the company's products, or forcing the Polish clothing concern LPP to suspend the sale of cashmere clothing in 2020 due to brutal practices in obtaining this raw material.

Thus, the consumer can consciously influence the prevention of ecosystem degradation and the improvement of the quality of social life through his choices, environmental empathy and ecological sensitivity. This also applies to the energy market, where the analysis of consumer behaviour and motivation in Poland was described in their works by, among others, Czarnecka M. [20] emphasizing the role of consumer market education, Nagaj R. [21] studying the cognitive distortions of energy end-users and Parzonko A.J., Balińska A., Sieczko A. [22] analysing the pro-environmental behaviour of generation Z.

Quantitative electricity market research has a multidimensional aspect. In the literature, you can find many articles on forecasting the demand and prices of electricity or the production of renewable energy [23]. Depending on the source of obtained energy, the forecasting of renewable energy market resources concerned: solar energy [24,25], wind energy [26-28], marine and ocean energy [29]. Currently, randomisation-based machine learning methods such as: Extreme learning Machines (ELM), Random Forrest (RF), Random Vector Functional Linc (RVFL), or Echo State Networks [ESN] are quite popular [25]. The following are also used to forecast renewable energy consumption: the k-nearest neighbours algorithm [30], and Artificial Neural Network (ANN) [31].

The use of Autoregressive Integrated Moving Average (ARIMA) models to forecast energy consumption, including renewable energy, can be found in [32]. The study took into account the consumption of coal, oil, gas and renewable energy along with the total energy consumption in 1970-2015. The research results indicated that energy consumption will increase until 2040, including the consumption of coal, oil, natural gas, renewable energy and total energy will grow at an average annual rate of $4.87 \%, 3.92 \%, 4.39 \%, 1.64 \%$ and $4.20 \%$ in the next 25 years. Another study taking into account, among others, ARIMA models in electricity market forecasting are [33]. It confirmed that the transformation and standardization of the original series allows the use of ARIMA models and on their basis better forecasts were built than with the use of other algorithms, especially in longterm forecasts.

When forecasting the hourly average wind speed at two observation sites in North Dakota, three types of ANN were used in [34]: adaptive linear element, backpropagation and radial basis function. In turn, in [35] the Generalized Regression Neural Network (GRNN) was used for long-term forecasting of electricity consumption.

Model Seasonal Autoregressive Integrated Moving Average (SARIMA) and the nonlinear autoregressive neural network (NARNET) were used to predict energy consumption based on historical data from the Mato Grosso Federal University [36]. A similar method of forecasting energy consumption can also be found in [37], where the ARIMA and ANN model were used. The ARIMA multiplicative seasonal model and the double seasonal Holt-Winters method were used in online electricity demand prediction for execution times from half an hour ahead to the next day at work [38]. The predictions made by the new Holt-Winters dual seasonal method surpass those of the traditional Holt-Winters method and the well-defined multiplicative double-season ARIMA model. An innovative approach to forecasting energy consumption was applied in [39], where the combined Bootstrap aggregation methods (Bagging) were used. In turn, in [40] energy consumption projections for two real university buildings from Ecuador and Spain were built. Smoothing methods, simple and multiple regressions and ARIMA models were used. The results of the conducted analyses showed that the forecasts by the Holt-Winters and ARIMA methods have the best accuracy of electricity demand. 
The literature review presented in this part of the work allows only to notice a wide spectrum of possibilities of forecasting electricity consumption. A comprehensive review of electricity price forecasting methods is included in [41]. A literature review providing methodology's verification of the acceptability assessment of the constructed energy consumption forecasts can be found in the works of Fabricio [42] and Lampaga [43]. Indications of the acceptability of the forecasts can be found in reports [44-46].

For the highly effective functioning of the energy market, an information resource about electricity as a commodity is indispensable. As already mentioned, the behaviour and motives of end users in terms of energy consumption, including renewable energy, are difficult to predict due to the complexity and unnecessary rationality of the decisionmaking process. It is, however, possible to forecast the results of these behaviours, i.e., energy consumption. The main goal of the work is to examine the prospects for a greater share of renewable energy sources in obtaining energy in Poland based on the analysis of attitudes and opinions of consumers on the retail energy market, legal regulations and the energy balance. The research objective was a retrospective literature study on consumer energy behaviour and attitudes in Poland, along with a description of the internal conditions of the consumer energy market. The second aim was to assess the forecasting capabilities of popular machine learning models including neuron networks together with the XGBost and SARIMA model. The models used can be a certain alternative to the energy forecasting methods used so far. Forecasts for daily, weekly, monthly and quarterly energy consumption were built, along with the prediction of the share of RES, based on selected adaptive algorithms, machine learning and deep learning. The time series study uses the data of daily electricity consumption for 2015-2021 obtained from the cire.pl website based on ENTSO-E (European Network of Transmission System Operators for Electricity).

\section{Materials and Methods}

End consumers on the electricity market are in a compulsive and ambiguous situation for themselves. Continuous technological progress causes that consumers, on the one hand, use more and more devices that draw electricity. However, on the other hand, the growing ecological trends cause them to evolve their behaviour and shift from self-consumption to eco-consumption [47].

Eco-consumption is strongly supported by the European Union and in accordance with Directive 2009/28/EC of the European Parliament and of the Council of 23 April 2009 on the promotion of the use of energy from renewable sources, Member States were required to ensure a certain share of energy from renewable sources in gross final energy consumption in 2020. The mandatory national overall targets consisted of an assumed $20 \%$ share of renewable energy in gross final energy consumption in the Community. For Poland, this target was set at $15 \%$ and it is initially known that this ceiling has not been reached. The national share of RES in gross final energy consumption consists of energy consumption in electricity, heating and transport. According to experts, preliminary forecasts suggest that this share for Poland will approach 14\% in 2020 and achieve the $15 \%$ target in 2021. Percentage changes in the share of energy from renewable sources in gross final energy consumption in Poland in 2010-2019, according to Statistics Poland and Eurostat data, are presented in Figure 4.

The next strategic goals of changes in energy consumption were adopted by the European Council on 24 October 2014 as part of the Community's climate and energy policy until 2030 (revised in December 2018). It was established for the Member States to increase the share of energy from renewable sources in gross final energy consumption to at least $32 \%$ and to increase energy efficiency by at least $32.5 \%$. According to the Appendix A to the resolution no. 22/2021 of the Council of Ministers of 2 February 2021 Poland's Energy Policy until 2040 [Appendix A] [48] - taking into account the national potential of renewable resources, competitiveness of RES technology, technical possibilities of their work in National Energy System, as well as the challenges related to the development of RES in transport and heating, Poland declares to achieve a $23 \%$ share of RES in gross final 
energy consumption in 2030 (measured as total consumption in electricity, heating and cooling and for transport purposes) as part of the participation in the implementation of the EU-wide target for 2030. However, in the 2040 perspective, the share of RES is estimated at least at $28.5 \%$.

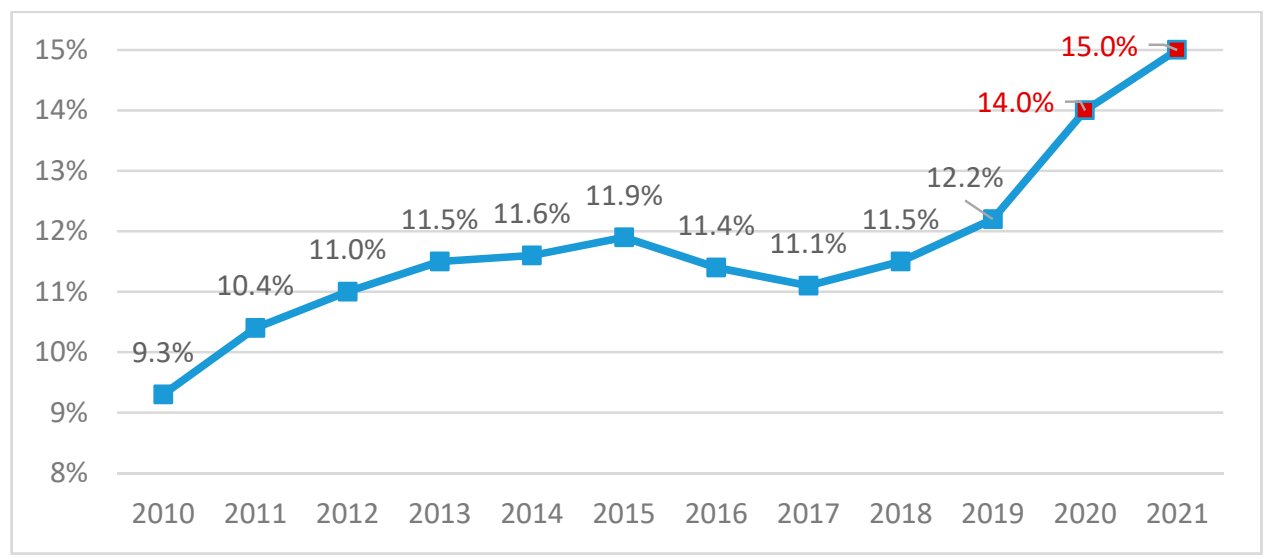

Figure 4. Share of RES in gross final energy consumption in Poland.

In publications analysing the behaviour and motivations of consumers on the energy market, a growing pro-environmental and ecological awareness can be noticed. In this article, the results of household surveys in Ireland, Switzerland, Japan, Australia and Poland were used to analyze changes in attitudes of energy consumers. Researchers, D. Clancy, D. O'Loughlin [49] in Ireland, S. L. Hille [50] in Switzerland and E. Nakamura [51] in Japan, analyzed personality traits and behavioral determinants related to energy savings, while the discrepancy between the knowledge, values, intentions declared by energy consumers with their observable changes in behavior was investigated by E. R. Frederiks, K. Stenner and E.V. Hobman [52] in Australia. Last but not least, the analysis of cognitive distortion level of consumers in the electricity market in Poland was carried out by Nagaj R. [53].

Answers to the question whether there is an ecological revolution in the thinking about the energy market in Polish society were given by the results of the IPSOS poll for oko.press conducted on 26-29 August 2019 using the CATI (Computer-Assisted Telephone Interviewing) method on a nationwide representative sample of 1006 people [54]. Distribution of answers to the question asked: "If you were to decide in which 2 main sources of energy Poland should invest and improve them, what would you indicate?" is shown in Figure 5:

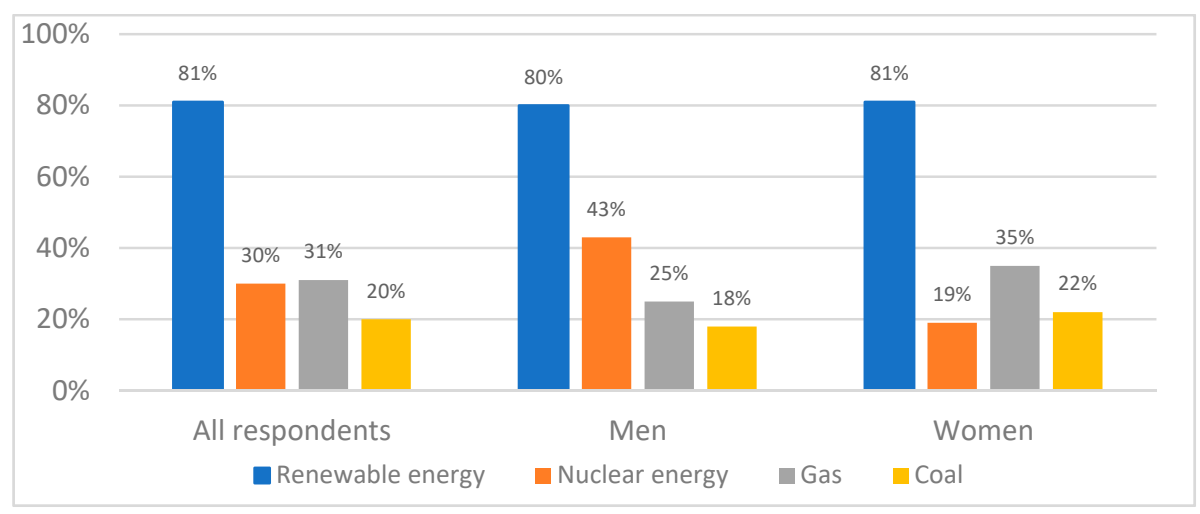

Figure 5. Preferred energy sources by consumers (by gender) in which Poland should invest.

The indicated preferences (Figure 5) prove very favourable opinions of Polish consumers on investments in renewable energy sources (RES) and a high awareness of the need for the country's energy transformation towards RES. There was a marked difference 
in the assessment of nuclear energy, the development of which was accepted by more than twice as many men as women. Such decisions are associated with a lower propensity to take risks in women.

On the other hand, responses to the question about identifying two investment preferred energy sources for Poland, analysed according to the age of the respondents, clearly suggest greater ecological and pro-social awareness among young people. In the 18-29 age group, the advantage of RES and nuclear energy is nearly three times greater than that of coal and gas that pollute the environment. In generations of 30-39 years, 40-49 years and $50-59$ years, this advantage is slightly more than two times, and in the case of the oldest respondents it is 1.8 (Figure 6). It is positive that all respondents, regardless of gender and age, point to the reduction of coal in the Polish energy economy.

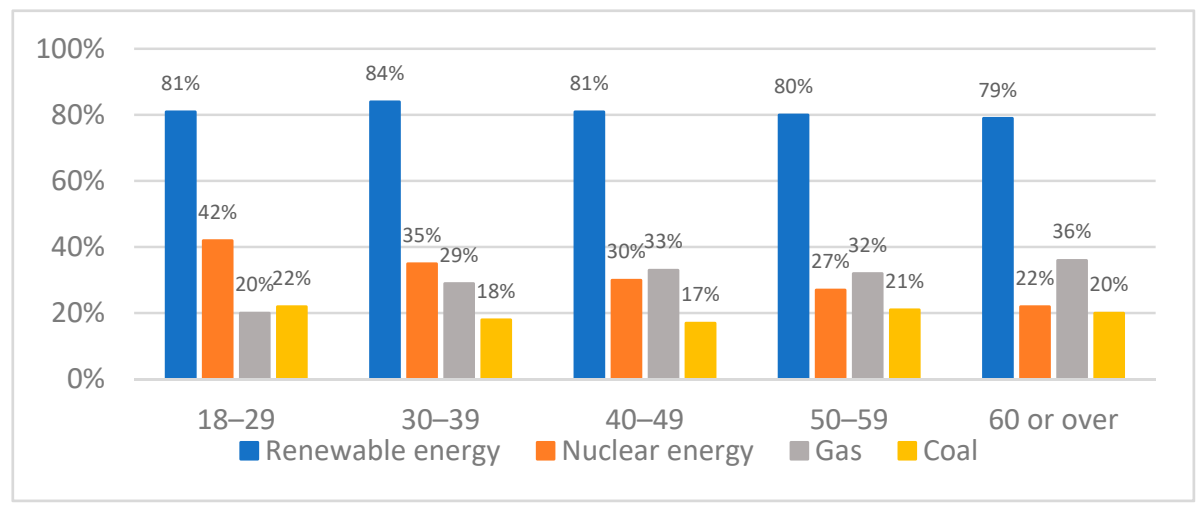

Figure 6. Preferred energy sources by consumers (by age) in which Poland should invest.

The analytical and prognostic part of this study was performed on the basis of ENTSOE data collected from the cire.pl website. This data represents a time series of aggregated daily electricity consumption expressed in Gigawatt hours (Gwh). The range of the data covers the dates from 31 December 2014 to 30 June 2021 (Figure 7).

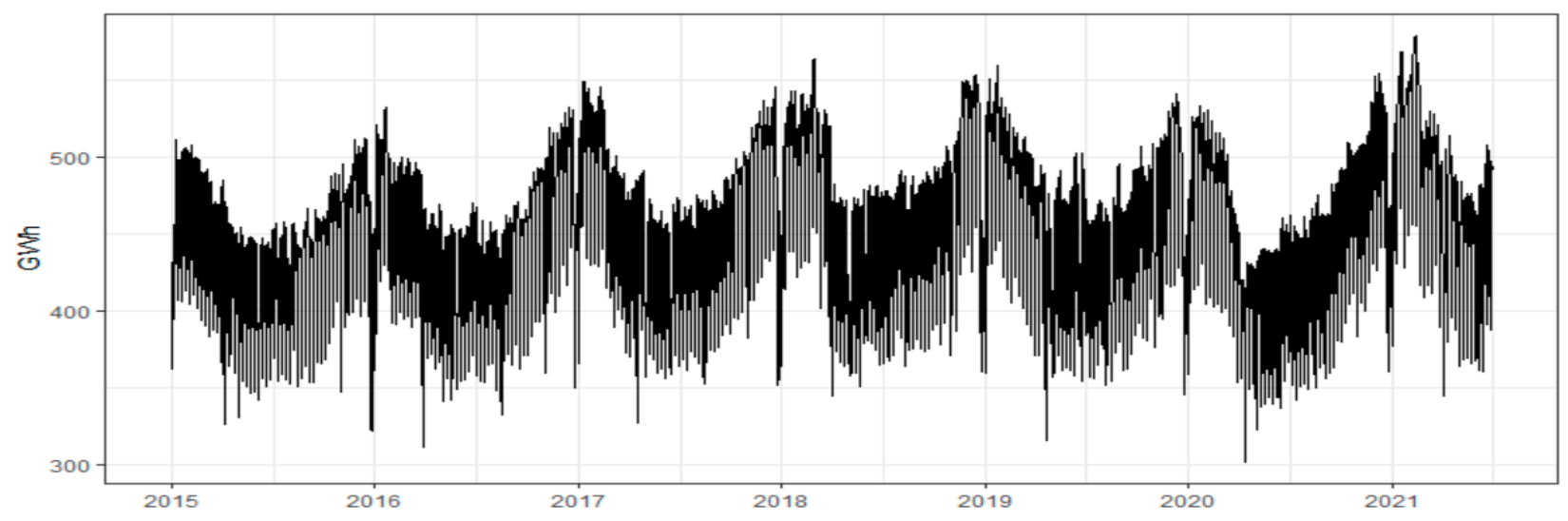

Figure 7. Daily energy consumption in Poland from 31 December 2014 to 30 June 2021 (in GWh).

Two time points with missing data were observed in the set. To complete the series, an imputation method was used based on linear interpolation for data with seasonality, which was implemented in the forecast::na.interp function in the R package [55]. In turn, for the models requiring the frequency determination, the value 7 was adopted, obtained from calling the forecast::findfrequency function [55].

Data analysis consisted of two elements. As part of the initial data analysis, the data were broken down into monthly parts and basic descriptive statistics (mean, standard deviation, coefficient of variation) were calculated. The study focused not only on the 
forecast of electricity consumption in Poland, but also on the assessment of the accuracy of such forecasts. The primary consideration was the selection of the models to be used for these forecasting efforts. On the basis of the conducted literature research (see Introduction) and own preliminary calculations and simulations, 5 models were finally selected and then subjected to a broader analysis described in this paper. At this stage, we used: XGBoost [56], SARIMA model with automatic model selection based on the stepwise selection of model hyperparameters [57], the adaptive exponential smoothing model Smoothing State Space Model (ETS) with automatic selection of smoothing and error parameters, trend and seasonality [58] and models using artificial neural networks: General Regression Neural Network (GRNN) [59,60], Neural Network Time Series Forecasts (NNETAR) [55]. Neural networks were used as computational models for the machine learning model, XGBoost and the time series, SARIMA model. It is worth noting that application of some modern models (especially XGBoost) in this context can be seen as partially experimental. The nature of this experimental approach makes the discussion of the obtained model structures not as obvious as in the case of the SARIMA model, e.g., typically, machine learning models were based on decision trees and neural networks. A description of the models used can be found below.

XGBoost is an advanced machine learning method based on gradient boosting. In the settings of this model our choice is "gblinear" booster, which means a linear function model estimation for each weak learner. The final score consists of the weighted scores of the weak learners. The algorithm iteratively fits the regression models based on the given predictors until the optimum is achieved.

In the presented analysis, the model predictors were delayed daily values of electricity consumption. The model was built on delays not older than 3 years. The MAE error was chosen as the optimization criterion in the iterative improvement of the fit of the regression model.

The ETS function, in turn, creates a model belonging to the class of exponential smoothing models. They are identified by a triple: error type, trend type, seasonality type. In the case of the analysis, the ETS model selected was the Additive, Additive Damped and Additive model in each scenario.

The GRNN is a single-pass neural network which uses a Gaussian activation function in the hidden layer [60]. It consists of input, hidden, summation, and division layers. The NNETAR is a feed-forward neural networks with a single hidden layer and lagged inputs for forecasting univariate time series. In presented analysis the average of 20 networks was performed.

The daily energy consumption forecast was carried out in the following three scenarios (Table 2).

Table 2. Forecasting scenarios.

\begin{tabular}{ccccc}
\hline Scenario Name & \multicolumn{2}{c}{ Train Dates } & \multicolumn{2}{c}{ Valid Dates } \\
\hline & from & to & from & to \\
\hline Quarterly horizon & $2014-12-31$ & $2021-03-31$ & $2021-04-01$ & $2021-06-30$ \\
Monthly horizon & $2014-12-31$ & $2021-05-31$ & $2021-06-01$ & $2021-06-20$ \\
Weekly horizon & $2014-12-31$ & $2021-06-23$ & $2021-06-24$ & $2021-06-30$ \\
\hline
\end{tabular}

In order to determine the quality of forecasts of daily energy consumption, the relative ex-post error, MAPE, MPE, MAE, MSE, RMSE indicators were calculated on the validation data. In the case of quarterly, monthly and weekly forecasts, using the sum of quarterly, monthly of weekly forecasts, the relative ex-post error determined on the validation set was used. Additionally, quarterly, monthly and weekly forecasts of energy consumption covered by the $20 \%$ and $32 \%$ share of renewable energy are also provided (these scenarios are recommended by the European Council). 


\section{Forecasting Results}

When analysing the values of descriptive statistics (Figure 8), it can be seen that the highest daily consumption in each surveyed year was recorded in the winter months. January is usually the month with the highest consumption. In 2018, February was the month with the highest energy consumption, exceptionally. Among the remaining monthly averages, the average consumption for April and May 2020 are the lowest. The reduced energy consumption in these months can be associated with the introduction of restrictions on the operation of certain sectors of the economy during the first wave of the COVID-19 pandemic.

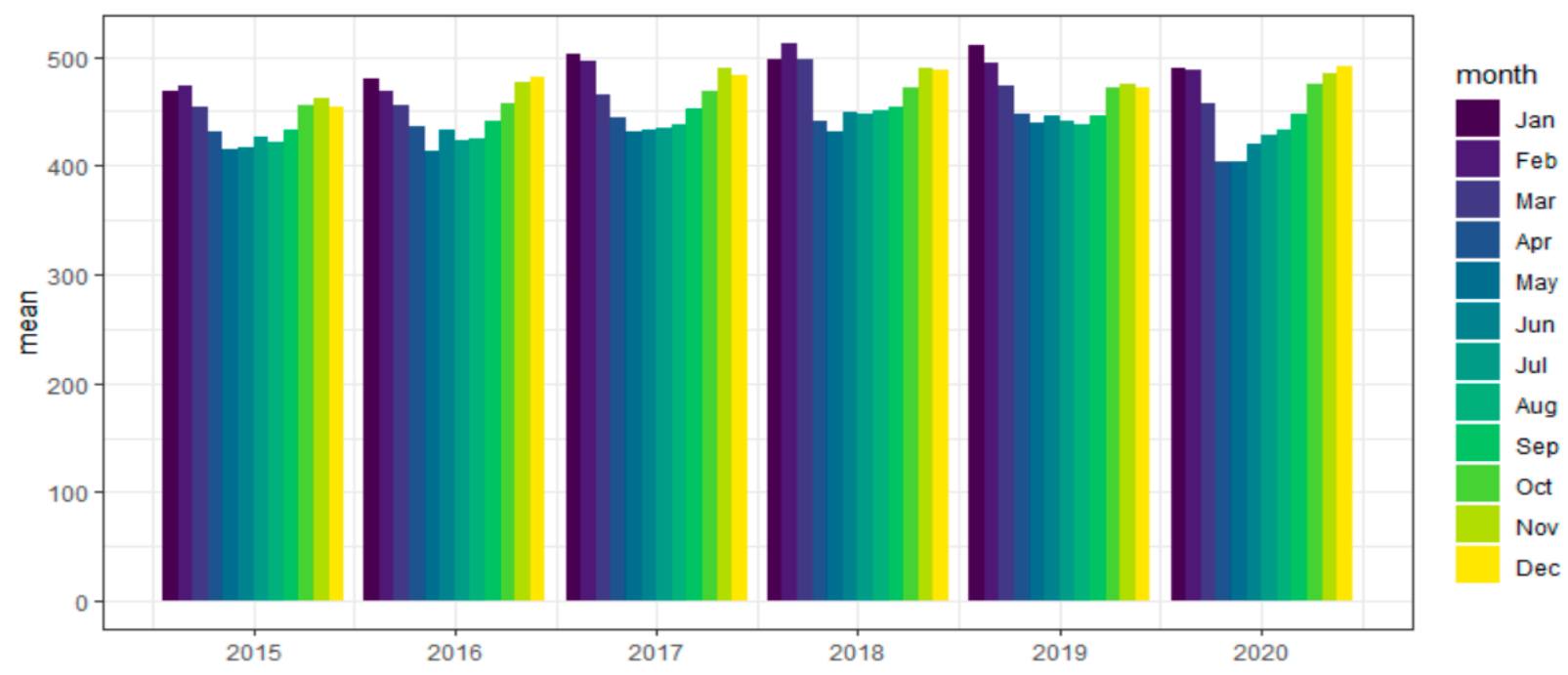

Figure 8. Daily consumption-means in months 2015-2020 (in GWh).

The within-month variation in daily energy consumption in 2015-2020 was not constant throughout the year (Figures 9 and 10). It can be observed that in each of the analysed years, the greatest differentiation was observed in the last month.

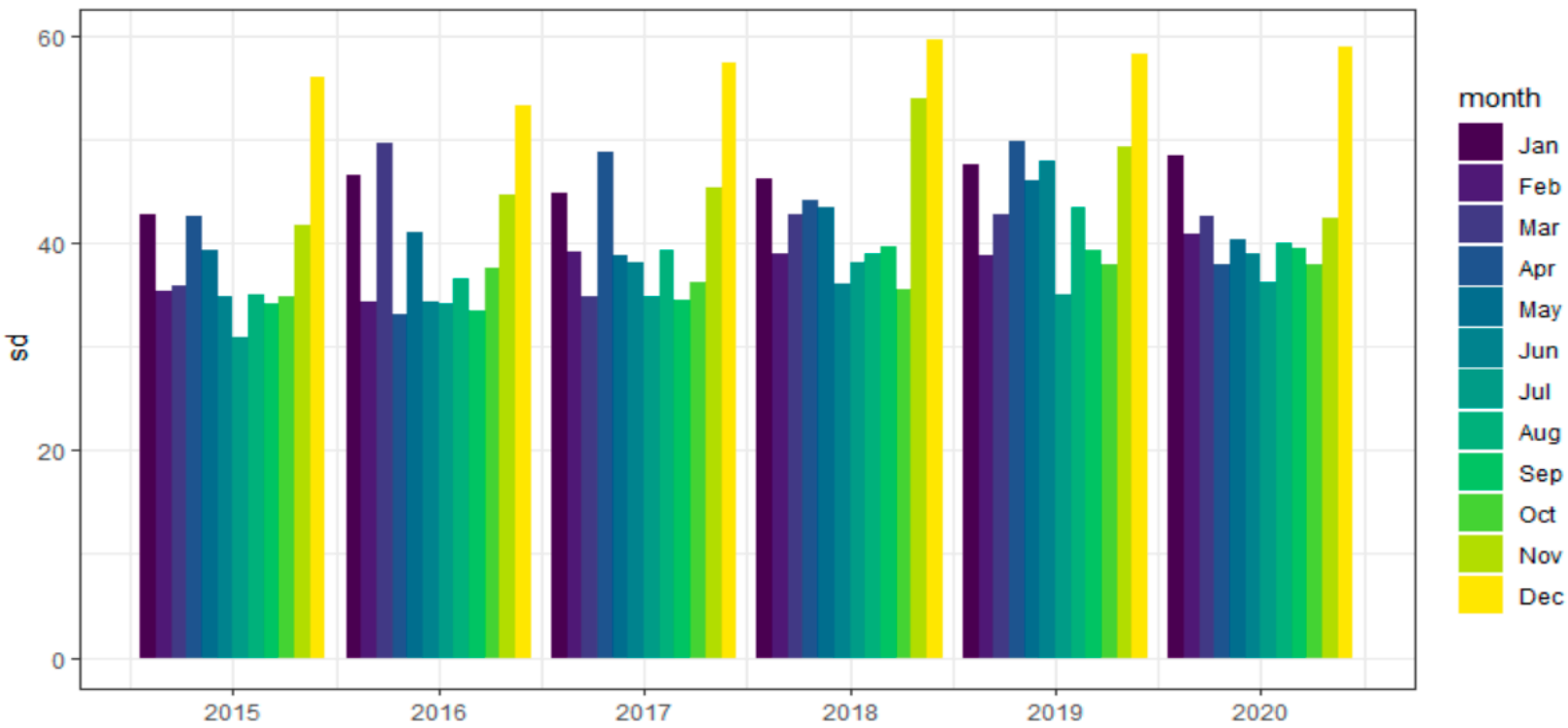

Figure 9. Daily consumption—standard deviation in months 2015-2020 (in GWh). 


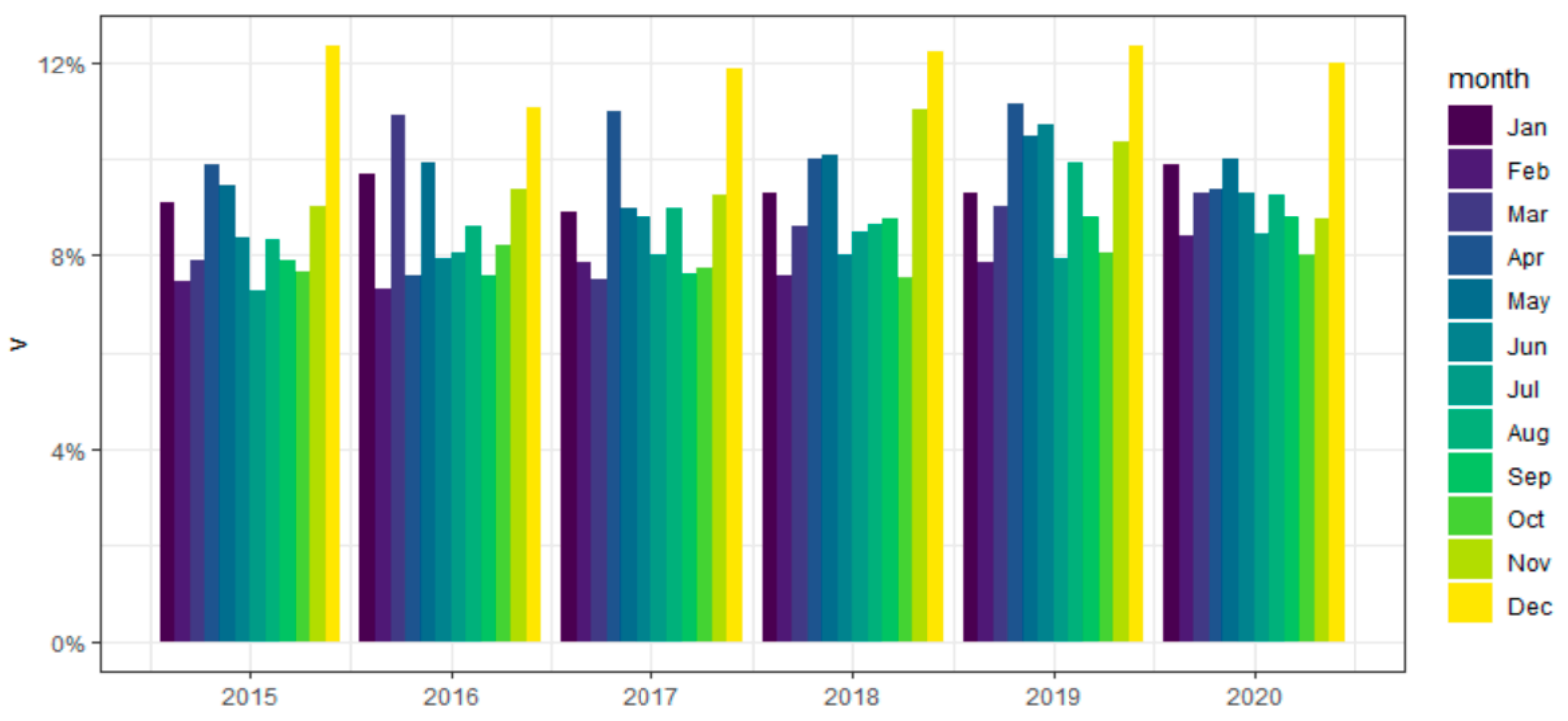

Figure 10. Daily consumption-coef. of volatility in months 2015-2020.

Figures 11-13 presents actual data and forecasts of daily energy consumption in Poland. In addition, the boxplots of the relative errors of forecasts for individual methods for the quarterly $(\mathrm{Q})$, monthly $(\mathrm{M})$ and weekly $(\mathrm{W})$ horizon of the daily energy consumption forecast in Poland are presented. The Appendix A contains Tables A1-A3 with the obtained results of the error measures of the forecasts obtained (MAPE, MPE, MAE, MSE, RMSE).
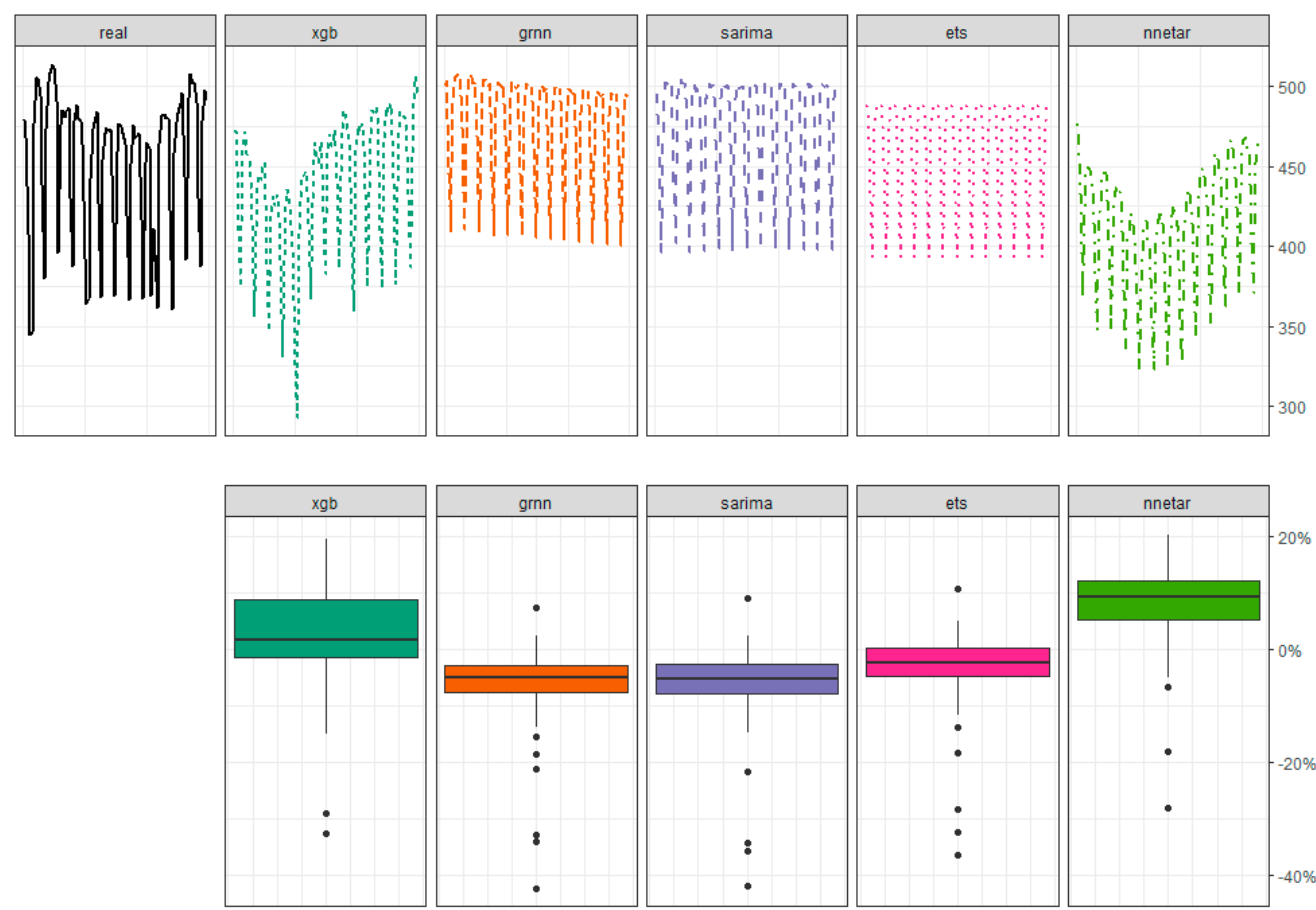

Figure 11. Quarterly forecast; Top panel: actual and forecast consumption course, bottom panel: boxplots of the relative error distribution of the forecasts in the tested scenario. 


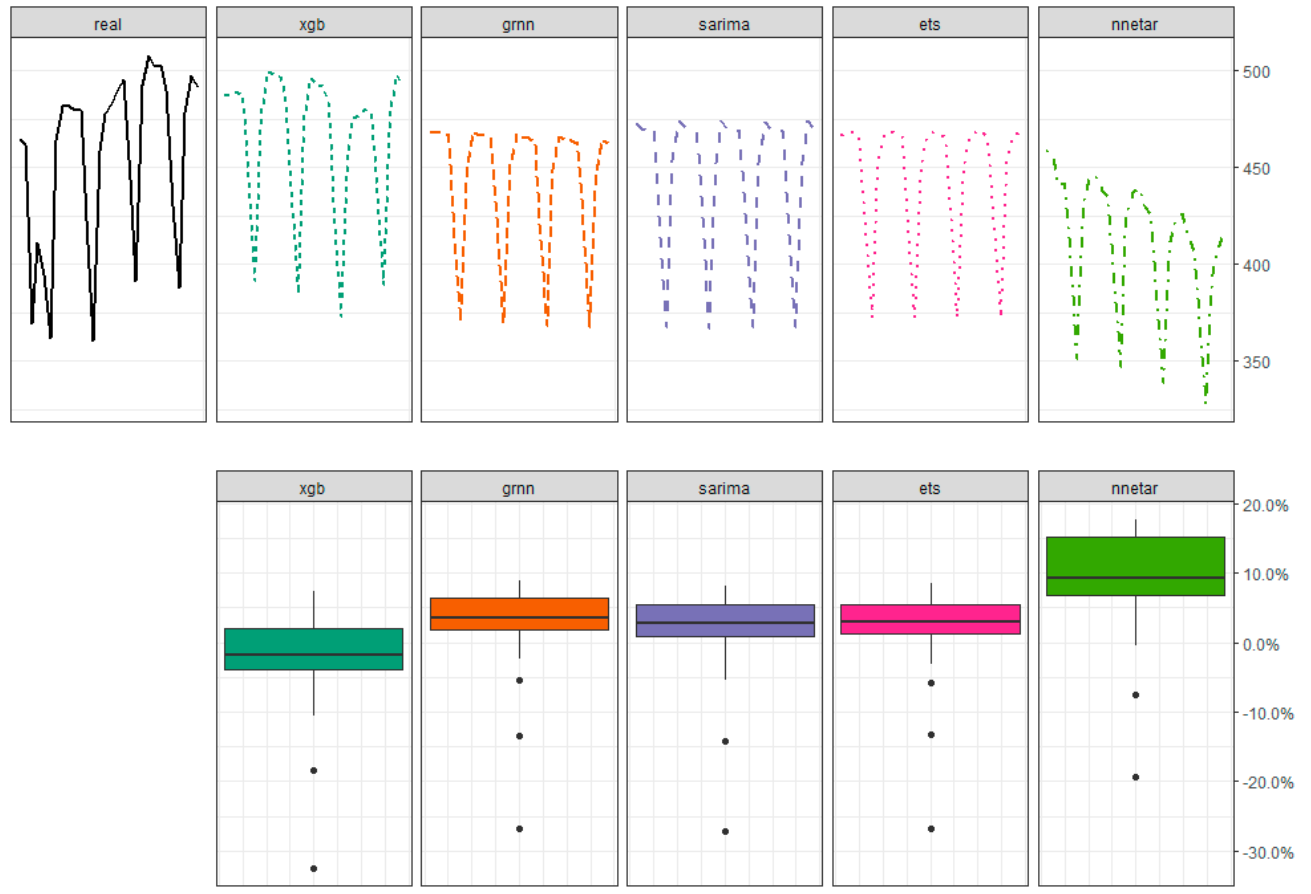

Figure 12. Monthly forecast (description as above).
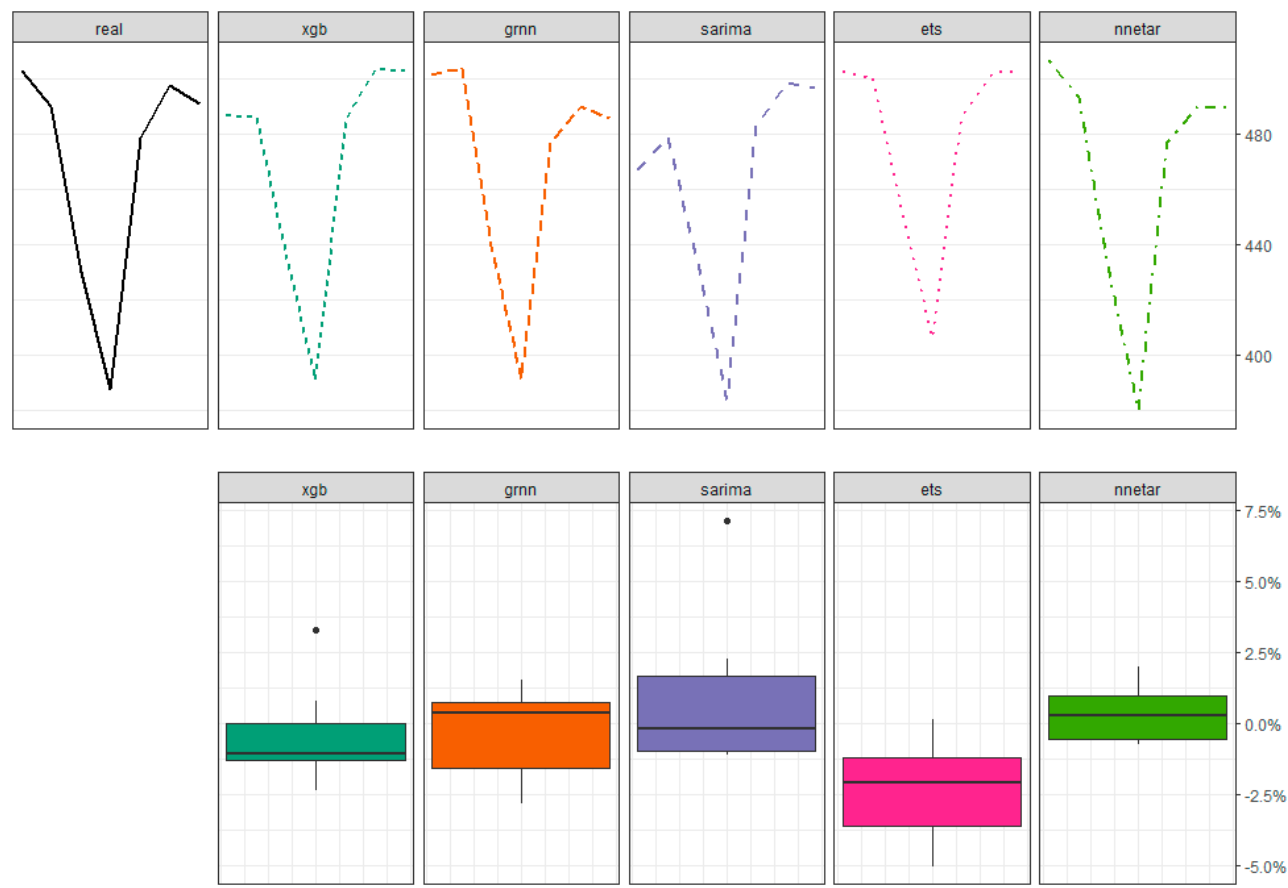

Figure 13. Weekly forecast (description as above).

In the case of the quarterly horizon, the lowest MAPE error values were obtained for the ETS and XGBoost forecasts. They were equal to $4.61 \%$ and $6.19 \%$, respectively. Slightly worse results were obtained for the SARIMA model (MAPE $=6.36 \%$ ). Additionally, observing the error boxplots, it can be noticed that these three methods are the most stable and are characterized by the lowest bias (which is also indicated by the MPE (Table A1) values, not exceeding $6 \%$ in terms of the modulus). In the quarterly scenario, the forecasts of daily energy consumption obtained with the XGBoost algorithm are generally underestimated. In turn, the forecasts built with the help of ETS and SARIMA slightly overestimate the real value of daily energy consumption. 
In the case of the monthly horizon, the forecasts based on the SARIMA and ETS models are the most accurate $(\mathrm{MAPE}=4.92 \%$ and $\mathrm{MAPE}=5.2 \%$ ). The predictions obtained from these models are the most stable (p. Figures 11-13). However, it is worth noting that these forecasts slightly lower the actual value of daily energy consumption. They are also much less biased than those in the quarterly scenario-MPE does not exceed the value of $3 \%$ in terms of the module.

For the weekly horizon, the best forecasts were obtained using the NNETAR (MAPE $=1.25 \%$ ), GRNN $(\mathrm{MAPE}=1.32 \%)$ and SARIMA (MAPE $=1.96 \%)$ models. The most stable forecasts (the smallest spread of forecast error) was built using the NNETAR model. Nevertheless, the forecasts for energy consumption were somewhat overestimated.

Among the models used in the study, the SARIMA model has the greatest possible interpretation. In SARIMA approach the same model class in all scenario train data: SARIMA $(5,0,0)(2,1,0)_{7}$ has been obtained. The values of estimated hyperparameters are collected in Table 3.

Table 3. Estimated structural parameters of the SARIMA models.

\begin{tabular}{cccc}
\hline & $\mathbf{Q}$ & $\mathbf{M}$ & $\mathbf{W}$ \\
\hline ar1 & 0.765 & 0.754 & 0.755 \\
ar2 & -0.082 & -0.071 & -0.072 \\
ar3 & -0.009 & -0.009 & -0.009 \\
ar4 & 0.011 & 0.009 & 0.008 \\
ar5 & 0.066 & 0.066 & 0.066 \\
sar1 & -0.575 & -0.578 & -0.580 \\
sar2 & -0.316 & -0.318 & -0.321 \\
\hline
\end{tabular}

Q-Quarterly, M-Monthly, W-Weekly.

The form SARIMA $(5,0,0)(2,1,0)_{7}$ indicates that the model includes, among others, weekly differences delayed by 5 consecutive periods, i.e., 5 consecutive delays of differences from one week before and the next week. Additionally, it can be noticed that the obtained form of the models is very stable. Parameter estimates have very similar values, regardless of the scenario under consideration.

Another element of the analysis was the assessment of the possibility of forecasting cumulative energy consumption. To this end, Tables 4 and 5 provide a forecast for the cumulative quarterly (Q), monthly $(\mathrm{M})$ and weekly $(\mathrm{W})$ consumption together with the relative forecast errors. In the case of the quarterly forecast, the smallest relative error was obtained for ETS $-2.76 \%$ (overestimated forecasts) and $2.83 \%$ for XGBoost (underestimated forecasts). For the monthly forecast, the best forecasts were obtained from SARIMA-error $1.73 \%$ (underestimated forecasts) and XGBoost $-1.76 \%$ (overestimated forecasts). For the weekly forecast, the best forecasts are obtained from the GRNN model $-0.33 \%$ (slightly overestimated forecasts) and XGBoost-error $0.85 \%$ (slightly underestimated forecasts) and NNETAR — error $0.96 \%$ (slightly underestimated forecasts).

Table 4. Sums of energy consumption-real vs. forecasts (in GWh).

\begin{tabular}{cccc}
\hline & $\mathbf{Q}$ & $\mathbf{M}$ & $\mathbf{W}$ \\
\hline real & 41,135 & 13,651 & 3277 \\
xgb & 39,972 & 13,891 & 3249 \\
grnn & 43,413 & 13,313 & 3288 \\
sarima & 43,394 & 13,415 & 3242 \\
ets & 42,271 & 13,371 & 3351 \\
nnetar & 37,007 & 12,357 & 3246 \\
\hline
\end{tabular}


Table 5. Relative errors of forecasts in percent.

\begin{tabular}{cccc}
\hline & $\mathbf{Q}$ & $\mathbf{M}$ & $\mathbf{W}$ \\
\hline xgb & 2.83 & -1.76 & 0.85 \\
grnn & -5.54 & 2.48 & -0.33 \\
sarima & -5.49 & 1.73 & 1.07 \\
ets & -2.76 & 2.05 & -2.25 \\
nnetar & 10.03 & 9.48 & 0.96 \\
\hline
\end{tabular}

Q-Quarterly, M-Monthly, W-Weekly.

Additionally, Tables 6 and 7 provide a $20 \%$ and 32\% forecast of quarterly, monthly and weekly demand from renewable energy sources. The percentages are in line with the requirements of achieving the RES targets for 2020 and 2030, respectively, set by the European Commission for the Community countries.

Table 6. $20 \%$ of the minimum demand for renewable energy (in GWh).

\begin{tabular}{cccc}
\hline & Q & M & W \\
\hline real & 8227 & 2730 & 655 \\
xgb & 7994 & 2778 & 650 \\
grnn & 8683 & 2663 & 658 \\
sarima & 8679 & 2683 & 648 \\
ets & 8454 & 2674 & 670 \\
nnetar & 7401 & 2471 & 649 \\
\hline
\end{tabular}

Q-Quarterly, M-Monthly, W-Weekly.

Table 7. 32\% of the minimum demand for renewable energy (in GWh).

\begin{tabular}{cccc}
\hline & $\mathbf{Q}$ & $\mathbf{M}$ & $\mathbf{W}$ \\
\hline real & 13,163 & 4368 & 1049 \\
xgb & 12,791 & 4445 & 1040 \\
grnn & 13,892 & 4260 & 1052 \\
sarima & 13,886 & 4293 & 1037 \\
ets & 13,527 & 4279 & 1072 \\
nnetar & 11,842 & 3954 & 1039 \\
\hline
\end{tabular}

Q-Quarterly, M-Monthly, W—Weekly.

The presented values (Tables 6 and 7) are suggestions of levels that to some extent meet the EU obligations for 2020 and 2030 in the field of electricity, because they do not constitute the full value of gross final energy consumption, which additionally includes consumption in heating and cooling, as well as for transport.

The obtained forecasts of the RES consumption are chosen from models with the lowest relative error. In the first scenario (assuming 20\% energy), forecasts of $8454 \mathrm{GWh}$ for the ETS models were obtained-quarter data, $2683 \mathrm{GWh}$ for the SARIMA model-monthly data and 658 GWh for the GRNN model-weekly data. In the second scenario (assuming $32 \%$ energy), the forecasts of 13,527 GWh were obtained for the ETS models-quarterly data, 4293 GWh for the SARIMA model-monthly data and 1052 GWh for the GRNN model-weekly data.

\section{Discussion}

It should be noted that all changes made in recent years in the regulatory policy with regard to the energy sector in Poland are largely determined by the energy policy of the European Union and the adopted directives. In addition, the need to care for the natural environment and the wider use of renewable energy sources play an increasingly important role in decisions taken by energy companies. Although the so-called distance act (introduced, among others, the obligation to erect new turbines only on the basis of local plans and the minimum distance of the device from residential buildings of at least 
10 times its total height) severely limited the development of onshore wind farms, but subsequent editions of the government support program "Mój Prąd" (My Electricity), launched in July 2019 (with the planned implementation by 2025), contributed to the boom in photovoltaics and a strong increase in electricity production from solar panels. As already mentioned, in 2020, it was 3.5 times higher than in 2019. Poland joined the global European trend here, because according to SolarPower Europe, at the end of 2020 in 27 EU Member States the installed capacity in photovoltaics amounted to 137.2 GW. In just 12 months, almost $19 \mathrm{GW}$ of capacity was added and it was the best annual result since 2011 (increase by 11\%) [61]. Undoubtedly, a strong motivation of Polish prosumers generating electricity in home photovoltaic micro-installations is the favourable barter settlement with the energy supplier. The possibility of using $80 \%$ of the electricity fed into the grid has encouraged hundreds of thousands of people to install PV installations. However, the Polish government is not entirely consistent in promoting RES, because the Ministry of Climate and Environment wants to abolish this system of deductions from January 1, 2022, which may discourage final energy consumers from investing in solar panels. Meanwhile, the Ministry of Development, Labour and Technology has prepared an amendment to the Distance Act (planned for implementation at the end of November 2021), which will be of great importance for the development of onshore wind energy, in response to the need to achieve the RES targets set by the European Commission. The act is to bring a significant impulse to the development of the RES industry in Poland and, with the appropriate scale of modern investments, it is to ensure the inflow of a large amount of cheap, "green" energy from onshore wind farms to the Polish energy system. It is good that the Polish government noticed that green energy is simply cheaper, because the growing prices of energy from coal and gas in Poland, the prices of fuels and $\mathrm{CO} 2$ emission allowances translate into the competitiveness of the Polish economy and one of the highest energy prices in the EU for the consumers of the retail market. In addition, as noted in the work, the modern consumer of the energy market is a customer who, apart from paying attention to maximizing utility or saving on bills, tries to be aware of the ecological problems of the world. The research of end-users of energy on the Irish, Swiss, Japanese, Australian and Polish market cited in the article prove that the motivations to save energy are mainly the result of quite complex behavioural rather than rational factors. The results of research on the energy market customers in Ireland and in Switzerland apart from personality traits previously associated with energy saving, such as-activity, economy, technical attitude, ecological awareness, revealed new personality traits of prosumershigh aversion to consumption, strong sense of caution in relation to personal finances and a clear interest in investing in energy-saving technologies. On the other hand, the study of determinants of behaviour related to saving electricity in Japanese households showed that the motivations to save energy are mainly the result of behavioural rather than rational factors. Replacing devices with energy-saving ones was reinforced by the understanding of the importance of saving energy and social pressure, not the sole desire to save energy. According to researchers from Australia, consumers often act in ways that both fail to align with their knowledge, and fall short of maximising their material interests. A growing body of research indicates that people prefer lower-value certainties over higher-value risks, evaluate things in relative rather than absolute terms, and are heavily influenced by the people around them. Additionally it's seems that energy consumers gain greater awareness of the value and need for sustainable energy practices, particularly amid growing public concerns over greenhouse gas emissions and climate change. This proves the observations quoted in the work of both the classics of economy theory L. Ch. Robbins and A. Smith, as well as the findings of the above-mentioned Nobel laureates from the trend of behavioural economics, D. Kahneman, V. L. Smith and R. H. Thaler, that the study of human behaviour is extremely important in identifying the causes of such and not other economic activities of a human being. In developing Poland, one of the main reasons for choosing services is the price, but in the case of the specifics of the domestic, expensive energy market, emotional, ethical and environmental attitudes are evident. It is 
documented by the mentioned research on the $\mathrm{Z}$ generation by Parzonko A.J., Balińska A., Sieczko A. and the presented results of research by R. Nagaj and the IPSOS survey. In the Nagaj study of households, it showed that a significant proportion of consumers are susceptible to cognitive distortions when making decisions on the electricity market. Almost $75 \%$ of the respondents underwent such behavioural distortions as: the certainty effect (preferring choices that are associated with certainty of their occurrence), narrow frames (analysis of a specific problem or phenomenon in isolation from the broader context) and accessibility error (paying excessive attention to remembered phenomena that are easy to recall). The research also resulted in conclusions that men are more susceptible to past memories, and women prefer stable market conditions and contracts based on long-term fixed rules to a greater extent. In turn, susceptibility to emotions increased as the amount of bills paid decreased. It should be noted that the offers of energy suppliers should place greater emphasis on providing customers with more tangible benefits for activities related to energy saving, because the billing of consumption itself does not lead to changes in consumer behaviour and pro-effective attitudes. On the other hand, the IPSOS survey proves the ecological awareness of Polish citizens, which already translates into attitudes of social involvement, which is a response to existential anxiety related to the life of future generations, climate change and the fate of our planet, which is endangered, among others, by the use of fossil fuels for energy production.

Young consumers are particularly aware of pro-environmental and pro-ecological activities. This is a group of customers who do not want to be passive market participants. Their free functioning on social media, on the one hand, allows for highly effective awareness of the importance of conscious consumption by broad social groups, and, on the other hand, for organizing effective consumer boycotts. In Poland, it was young people who drew attention to the growing problem of smog related to, among other things, obtaining heat energy from environmentally degrading fossil fuels. Involvement in the problem gave rise to the popularity of anti-smog mobile applications. On the other hand, the social pressure was so strong that it resulted in the government program "Czyste Powietrze" (Clean Air) with co-financing of the replacement of energy sources in households that pollute the environment.

The results of the calculated forecasts, apart from indicating which method gives the best results in forecasting electricity demand, may be a suggestion of the potential of energy production in GWh from renewable sources in order to achieve 20\% and 32\% (Tables 6 and 7) shares of energy from RES in gross final energy consumption set by the European Commission. In 2019, the negative foreign exchange balance amounted to 10,623.7 GWh, and in 2020, electricity imports from the Czech Republic, Sweden, Germany, Slovakia and Ukraine increased to a record level of 13.1 TWh net, which cost about PLN 3 billion [62]. Thus, there are capacities to be supplemented on the basis of domestic production, and renewable energy could be a factor that turns the negative balance into a positive one.

Due to the lower costs of green energy production and environmental and social benefits, Poland should strive to significantly increase the production of energy from renewable sources in the coming years, which is actively supported by both end-users of energy on the retail market and the increasingly numerous group of prosumers.

\section{Conclusions}

The purpose of the analysis of electricity consumption in Poland was to investigate the possibility of increasing the share of renewable sources in obtaining energy in Poland based on the attitudes and opinions of consumers on the retail energy market, legal regulations and the energy balance. It was found that the behaviour of electricity market consumers if burdened with behavioural and cognitive errors. This makes them unpredictable on their own and usually overlooked by practitioners and policymakers seeking to promote energy efficiency and save energy. The researchers quoted in the paper noticed certain trends in changes in the attitudes of energy market customers towards pro-environmental and pro- 
social sensitivity. In the modern world, especially consumers of the younger generations are becoming conscious creators of new, pro-ecological values. It has been shown in the examples presented in the article that they can actively participate in solving global problems in the field of environmental protection and sustainable practices in obtaining energy. In Poland, it is necessary to accelerate the already implemented changes in the energy and climate policy towards renewable energy sources. This is favoured by the opinions of consumers and pro-ecological attitudes presented in the paper, which, with appropriate state support, results in a rapid increase in the number of Polish prosumers who effectively produce green energy for their own needs and for the national power grid. It was indicated that Poland must meet the RES targets set for the coming years by the European Commission, which will probably result in a more economically advantageous energy balance of the country and savings both in the budget and in the portfolios of end consumers of energy in the retail market.

The second goal of the research was to build forecasts of electricity consumption in Poland using selected machine and deep learning methods. Due to the size of the dataset, it was decided to consider 3 scenarios for validating the daily forecasts along with determining simulated energy consumption forecasts for a quarter, month and week. Additionally, for weekly data, the quality of forecasts was evaluated using NMBE (the normalized mean bias error) and cvRMSE (the coefficient of variation root mean square error) measures recommended by ASHRAE, IMMVP, FEMP. For the vast majority of models, the obtained predictions were acceptable (see Tables A4-A6). It was proved that the applied methods show good prediction ability. In the case of monthly and weekly forecasts, quite accurate forecasts of energy consumption were obtained, characterized by small errors. As expected, as the prediction time horizon was shortened, the accuracy of the forecasts increased and the results became more stable. This confirms the possibility of using the prediction models and neural networks used in the work to forecast electricity demand in the short term. In summary, in the first scenario (assuming 20\% of energy from the RES), the following forecasts were obtained with the lowest relative error: $8454 \mathrm{GWh}$ for the ETS models-quarterly data, 2683 GWh for the SARIMA model-monthly data and $658 \mathrm{GWh}$ for the GRNN model-weekly data. In the second scenario (assuming 32\% of energy from the RES) following predictions were achieved: 13,527 GWh for the ETS modelsquarterly data, 4293 GWh for the SARIMA model-monthly data and 1052 GWh for the GRNN model-weekly data. These predictions could provide guidance to decision-makers in the implementation of EU programmes.

Author Contributions: Conceptualization M.Z.-S., M.C., K.F.; Writing M.Z.-S., M.C., K.F., K.P.; Economic analysis has been done by M.Z.-S. and M.C. Data analysis, selection of machine learning models was performed by K.F. and K.P. All authors have read and agreed to the published version of the manuscript.

Funding: This research received no external funding.

Institutional Review Board Statement: Not applicable.

Informed Consent Statement: Not applicable.

Data Availability Statement: The energy consumption data can be found at: https:/ /rynek-energiielektrycznej.cire.pl/st,33,554,me,0,0,0,0,0,zuzycie-energii-elektrycznej-w-polsce.html (accessed on 25 June 2021).

Conflicts of Interest: The authors declare no conflict of interest. 


\section{Appendix A}

MAPE, MPE are given in \%.

Table A1. Quaterly forecast error measure.

\begin{tabular}{lccccc}
\hline & MAPE & MPE & MAE & MSE & RMSE \\
\hline f_xgb & 6.19 & 2.7 & 27.54 & 1410.94 & 37.56 \\
f_grnn & 6.51 & -6.05 & 27.32 & 1342.88 & 36.65 \\
f_sarima & 6.36 & -5.95 & 26.89 & 1331.54 & 36.49 \\
f_ets & 4.61 & -3.24 & 19.28 & 853.46 & 29.21 \\
f_nnetar & 9.96 & 8.47 & 45.11 & 2373.45 & 48.72 \\
\hline
\end{tabular}

Table A2. Monthly forecast error measure.

\begin{tabular}{lccccc}
\hline & MAPE & MPE & MAE & MSE & RMSE \\
\hline f_xgb & 5.37 & -3.23 & 22.95 & 1057.4 & 32.52 \\
f_grnn & 5.56 & 2.04 & 24.83 & 969.2 & 31.13 \\
f_sarima & 4.92 & 1.35 & 21.74 & 833.57 & 28.87 \\
f_ets & 5.2 & 1.62 & 23.13 & 875.74 & 29.59 \\
f_nnetar & 13.06 & 11.24 & 60.37 & 4544.01 & 67.41 \\
\hline
\end{tabular}

Table A3. Weekly forecast error measure.

\begin{tabular}{lccccc}
\hline & MAPE & MPE & MAE & MSE & RMSE \\
\hline f_xgb & 1.95 & 0.75 & 9.44 & 131.46 & 11.47 \\
f_grnn & 1.32 & -0.39 & 6.17 & 54.88 & 7.41 \\
f_sarima & 1.96 & 1.01 & 9.5 & 213.47 & 14.61 \\
f_ets & 2.41 & -2.38 & 10.68 & 162.93 & 12.76 \\
f_nnetar & 1.25 & -1.25 & 5.75 & 51.72 & 7.19 \\
\hline
\end{tabular}

Table A4. Quarterly forecast error measure (in \%).

\begin{tabular}{lcc}
\hline & CvRMSE & NMBE \\
\hline f_xgb & 8.22 & -2.83 \\
f_grnn & 8.02 & 5.54 \\
f_sarima & 7.98 & 5.49 \\
f_ets & 6.39 & 2.76 \\
f_nnetar & 10.66 & -10.04 \\
\hline
\end{tabular}

Table A5. Monthly forecast error measure (in \%).

\begin{tabular}{lcc}
\hline & CvRMSE & NMBE \\
\hline f_xgb & 7.15 & 1.76 \\
f_grnn & 6.84 & -2.48 \\
f_sarima & 6.34 & -1.73 \\
f_ets & 6.50 & -2.05 \\
f_nnetar & 14.81 & -9.48 \\
\hline
\end{tabular}

Table A6. Weekly forecast error measure (in \%).

\begin{tabular}{lcc}
\hline & CvRMSE & NMBE \\
\hline f_xgb & 2.45 & -0.85 \\
f_grnn & 1.58 & 0.34 \\
f_sarima & 3.12 & -1.07 \\
f_ets & 2.73 & 2.26 \\
f_nnetar & 1.54 & -0.95 \\
\hline
\end{tabular}




\section{References}

1. Cire.pl (Energy Market Information Center). Available online: https:/ / www.cire.pl/item, 27178,7,0,0,0,0,0,uczestnicy-rynku-iformy-handlu-energia.html (accessed on 1 July 2021).

2. Ure.gov.pl (Energy Regulatory Office). Available online: https://www.ure.gov.pl/pl/energia-elektryczna/charakterystykarynku (accessed on 1 July 2021).

3. Dane.gov.pl. Available online: https://dane.gov.pl/pl/dataset/1199, energetyka-polska (accessed on 25 June 2021).

4. Jędra, M. Energy Transformation in Poland. Edition 2021. Available online: https://www.forum-energii.eu/public/upload/ articles / files/Raport_Transformacja\%20energetyczna\%20Polski_2021.pdf (accessed on 25 June 2021).

5. gramwzielone.pl. Available online: https://www.gramwzielone.pl/trendy/102320/kraje-unii-europejskiej-zwiekszylyprodukcje-energii-odnawialnej-jak-wypada-polska (accessed on 28 June 2021).

6. Eurostat. Database. Available online: https://ec.europa.eu/eurostat/statistics-explained/index.php?title=Renewable_energy_ statistics (accessed on 25 June 2021).

7. Magazynprzemysłowy.pl (Industrial Magazine). Available online: https://www.magazynprzemyslowy.pl/artykuly/oze-weuropie-ktore-panstwa-sa-obecnie-najbardziej-zielone (accessed on 25 June 2021).

8. Niemcewicz, P. Behavioral Economics-Hybrid of the Theory and Experiment. Probl. Wspótczesnej ekonomii 2018, 51, 9-19. Available online: https:/ / wnus.edu.pl/sip/file/article/download/14849.pdf (accessed on 25 June 2021). [CrossRef]

9. Robbins, L. An Essay on the Nature and Significance of Economic Science; Macmillan: London, UK, $1935 ;$ p. 16.

10. Backhouse, R.E.; Medema, S.G. On the Definition of Economics. J. Econ. Perspect. 2009, 23, 221-233. Available online: https: / / pubs.aeaweb.org/doi/pdfplus/10.1257/jep.23.1.221 (accessed on 25 June 2021). [CrossRef]

11. Smith, A. Teoria uczuć moralnych; PWN: Warsaw, Poland, 1989; pp. 126-353.

12. Beinhocker, E.D. The Origin of Wealth. The Radical Remaking of Economics and What It Means for Business and Society; Harvard Business School Press: Boston, MA, USA, 2006.

13. Polowczyk, J. Elements of Behavioral Economics in the Works of Adam Smith. Ekonomy 2010, 4, 493-522. Available online: https://www.researchgate.net/publication/296914806_ELEMENTS_OF_BEHAVIORAL_ECONOMICS_IN_THE_WORKS_ OF_ADAM_SMITH (accessed on 25 June 2021).

14. Kesternich, M.; Reif, C.; Rübbelke, D. Recent Trends in Behavioral Environmental Economics. Environ. Resour. Econ. 2017, 67, 403-411. Available online: https:/ /link.springer.com/article/10.1007/s10640-017-0162-3 (accessed on 25 June 2021). [CrossRef]

15. Kahneman, D.; Tversky, A. Prospect Theory: An Analysis of Decision under Risk. Econometrica 1979, 2, 263-292. Available online: https:/ / www.jstor.org/stable/1914185 (accessed on 20 July 2021). [CrossRef]

16. Smith, V.L. Experimental Economics: Induced Value Theory. Am. Econ. Rev. 1976, 66, 274-279. Available online: http: / / www.jstor.org/stable/1817233 (accessed on 20 July 2021).

17. Thaler, R. Toward a Positive Theory of Consumer Choice. J. Econ. Behav. Organ. 1980, 1, 39-60. Available online: https: / / www.sciencedirect.com/science/article/abs/pii/0167268180900517 (accessed on 20 July 2021). [CrossRef]

18. Thaler, R.H. Behavioral Economics: Past, Present, and Future. Am. Econ. Rev. 2016, 106, 1577-1600. Available online: https: / / www.aeaweb.org/articles?id=10.1257/aer.106.7.1577 (accessed on 20 July 2021). [CrossRef]

19. Richard, H. Thaler-Facts. NobelPrize.org. Nobel Prize Outreach AB. 2021. Available online: https://www.nobelprize.org/ prizes / economic-sciences/2017/thaler/facts / (accessed on 25 June 2021).

20. Czarnecka, M. Konsument na Rynaku ENERGII ELEKTRYCZNEJ; Wydawnictwo C.H. Beck: Warsaw, Poland, 2013.

21. Nagaj, R. Cognitive biases of households on the retail electricity market in Poland. Rynek Energii 2015, 2, 25-31. Available online: https:/ / www.cire.pl/pokaz-pdf-\%252Fpliki\%252F2\%252F04nagajzet15.pdf (accessed on 27 July 2021).

22. Parzonko, A.J.; Balińska, A.; Sieczko, A. Pro-Environmental Behaviors of Generation Z in the Context of the Concept of Homo Socio-Oeconomicus. Energy 2021, 14, 1597. [CrossRef]

23. Hong, T.; Pinson, P.; Wang, Y.; Weron, R.; Yang, D.; Zareipour, H. Energy Forecasting: A Review and Outlook. IEEE Open Access J. Power Energy 2020, 7, 376-388. [CrossRef]

24. Zeng, J.; Qiao, W. Short-term solar power prediction using a support vector machine. Renew. Energy 2013, 52, 118-127. [CrossRef]

25. Ser, J.D.; Casillas-Pérez, L.; Cornejo-Bueno, L.; Prieto-Godino, J.; Sanz-Justo, C.; Casanova, M.; Salcedo-Sanz, S. Randomizationbased Machine Learning in Renewable Energy Prediction Problems: Critical Literature Review, New Results and Perspectives. arXiv 2021, arXiv:2103.14624.

26. Salcedo-Sanz, S.; Ortiz-Garc1, E.G.; Perez-Bellido, A.M.; Portilla-Figueras, A.; Prieto, L. Short term wind speed prediction based on evolutionary support vector regression algorithms. Expert Syst. Appl. 2011, 38, 4052-4057. Available online: https: //www.sciencedirect.com/science/article/abs/pii/S0957417410010249 (accessed on 30 June 2021). [CrossRef]

27. Ortiz-Garcia, E.G.; Salcedo-Sanz, S.; Perez-Bellido, A.M.; Gascon-Moreno, J.; Portilla-Figueras, J.A.; Prieto, L. Short-term wind speed prediction in wind farms based on banks of support vector machines. Wind. Energy 2011, 14, 193-207. [CrossRef]

28. Augustyn, A.; Kamiński, J. A Review of Methods Applied for Wind Power Generation Forecasting. Polityka Energetyczna 2018, 21, 139-150. [CrossRef]

29. Cuadra, L.; Salcedo-Sanz, S.; Nieto-Borge, J.; Alexandre, E.; Rodriguez, G. Computational intelligence in wave energy: Comprehensive review and case study. Renew. Sustain. Energy Rev. 2016, 58, 1223-1246. [CrossRef]

30. Mangalova, E.; Shesterneva, O. K-Nearest Neighbors for GEFCom2014 Probabilistic Wind Power Forecasting. Int. J. Forecast. 2016, 32, 1067-1073. [CrossRef] 
31. Kalogirou, A.S. Artificial neural networks in renewable energy systems applications: A review. Renew. Sustain. Energy Rev. 2001, 5, 373-401. Available online: https:/ /www.sciencedirect.com/science/article/abs/pii/S1364032101000065 (accessed on 1 July 2021). [CrossRef]

32. Ozturk, S.; Ozturk, F. Forecasting Energy Consumption of Turkey by Arima Model. J. Asian Sci. Res. 2018, 8, 52-60. [CrossRef]

33. Torres, J.L.; Garcia, A.; De Blas, M.; De Francisco, A. Forecast of hourly average wind speed with ARMA models in Navarre. Sol. Energy 2005, 79, 65-77. [CrossRef]

34. Li, G.; Shi, J. On comparing three artificial neural networks for wind speed forecasting. Appl. Energy 2010, 87, 2313-2320. [CrossRef]

35. Aribowo, W.; Muslim, S.; Basuki, I. Generalized Regression Neural Network For Long-Term Electricity Load Forecasting. In Proceedings of the 2020 International Conference on Smart Technology and Applications (ICoSTA), Surabaya, Indonesia, 20 February 2020; pp. 1-5. Available online: https://www.researchgate.net/publication/340962748_Generalized_Regression_ Neural_Network_For_Long-Term_Electricity_Load_Forecasting (accessed on 1 July 2021).

36. Zancanaro, J.A. Energy Consumption Forecasting Using SARIMA and NARNET: An Actual Case Study at University Campus. In Proceedings of the 2019 IEEE PES Innovative Smart Grid Technologies Conference-Latin America (ISGT Latin America), Gramado, Brazil, 15-18 September 2019; pp. 1-6.

37. Nichiforov, C.; Stamatescu, I.; Fagarasan, I.; Stamatescu, G. Energy consumption forecasting using ARIMA and neural network models. In Proceedings of the 5th International Symposium on Electrical and Electronics Engineering (ISEEE), Galati, Romania, 20-22 October 2017; Available online: https:/ /ieeexplore.ieee.org/xpl/conhome/8125502/proceeding (accessed on 1 July 2021).

38. Taylor, J. Short-term electricity demand forecasting using double seasonal exponential smoothing. J. Oper. Res. Soc. 2003, 54, 799-805. [CrossRef]

39. Oliveira, E.; Oliveira, F.C. Forecasting mid-long term electric energy consumption through bagging ARIMA and exponential smoothing methods. Energy 2018, 144, 776-788. [CrossRef]

40. Serrano-Guerrero, X.; Siavichay, L.F.; Clairand, J.M.; Escrivá-Escrivá, G. Forecasting Building Electric Consumption Patterns. In Advances in Emerging Trends and Technologies; Botto-Tobar, M., León-Acurio, J., Díaz Cadena, A., Montiel Díaz, P., Eds.; Springer: Cham, Swizterland, 2020; Volume 1067. [CrossRef]

41. Weron, R. Electricity price forecasting: A review of the state-of-theart with a look into the future. Int. J. Forecast. 2014, 30, 1030-1081. [CrossRef]

42. Fabrizio, E.; Monetti, V. Methodologies and advancements in the calibration of building energy models. Energies 2015, 8, 2548-2574. [CrossRef]

43. Lamagna, M.; Nastasi, B.; Groppi, D.; Nezhad, M.M.; Garcia, D.A. Hourly energy profile determination technique from monthly energy bills. Build Simul 2020, 13, 1235-1248. [CrossRef]

44. FEMP. Federal Energy Management Program, MEV Guidelines: Measurement and Verification for Federal Energy Projects Version 3.0; U.S. Department of Energy Federal Energy Management Program: Washington, DC, USA, 2008.

45. Coakley, D.; Raftery, P.; Keane, M. A review of methods to match building energy simulation models to measured data. Renew. Sustain. Energy Rev. 2014, 37, 123-141. [CrossRef]

46. ASHRAE. Guideline 14-2002: Measurement of Energy Demand and Savings; American, Society of Heating, Refrigerating and Air-Conditioning Engineers: Atlanta, GA, USA, 2002.

47. Smyczek, S. Edukacja rynkowa konsumentów na rynku energii elektrycznej. In Konsument na rynku ENERGII ELEKTRYCZNEJ; Czarnecka, M., Ed.; Wydawnictwo C.H. Beck: Warsaw, Poland, 2013.

48. Załącznik do uchwały nr 22/2021 Rady Ministrów z dnia 2 Lutego 2021 r. Polityka Energetyczna Polski do 2040 r. Available online: https:/ / www.gov.pl/web/klimat/polityka-energetyczna-polski (accessed on 27 July 2021).

49. Clancy, D.; O'Loughlin, D. Identifying the 'energy champion': A consumer behaviour approach to understanding the home energy conservation market in Ireland. Int. J. Nonprofit Volunt. Sect. Mark. 2002, 7, 258-270. [CrossRef]

50. Hille, S.L. The Myth of the Unscrupulous Energy User's Dilemma: Evidence from Switzerland. J. Consum. Policy 2016, 39, 327-347. [CrossRef]

51. Nakamura, E. Electricity saving behavior of households by making efforts, replacing appliances, and renovations: Empirical analysis using a multivariate ordered probit model. Int. J. Consum. Stud. 2016, 40, 675-684. [CrossRef]

52. Frederiks, E.R.; Stenner, K.; Hobman, E.V. Household energy use: Applying behavioural economics to understand consumer decision-making and behaviour. Renew. Sustain. Energy Rev. 2015, 41, 1385-1394. [CrossRef]

53. Nagaj, R. Behavioral methods used to study consumer bevaviour on the electricity market. Rynek Energii 2018, 3, 3-8.

54. Available online: https://oko.press/az-81-proc-chce-oze-wegla-20-proc-im-mlodsi-tym-bardziej-eko-radykalni-kobiety-bojasie-atomu/ (accessed on 15 July 2021).

55. Hyndman, R.; Athanasopoulos, G.; Bergmeir, C.; Caceres, G.; Chhay, L.; O’Hara-Wild, M.; Petropoulos, F.; Razbash, S.; Wang, E.; Yasmeen, F. Forecast: Forecasting Functions for Time Series and Linear Models. R Package: Version 8.15. 2021. Available online: https: / / pkg.robjhyndman.com/forecast/ (accessed on 15 July 2021).

56. Chen, T.; Guestrin, C. XGBoost: A Scalable Tree Boosting System. In Proceedings of the 22nd ACM SIGKDD International Conference on Knowledge Discovery and Data Mining, San Francisco, CA, USA, 13-17 August 2016; ACM: New York, NY, USA, 2016 ; pp. 785-794. [CrossRef]

57. Hyndman, R.J.; Khandakar, Y. Automatic time series forecasting: The forecast package for R. J. Stat. Softw. 2008, 26. [CrossRef] 
58. Hyndman, R.J.; Koehler, A.B.; Snyder, R.D.; Grose, S. A state space framework for automatic forecasting using exponential smoothing methods. Int. J. Forecast. 2002, 18, 439-454. [CrossRef]

59. Chasset, P.O. GRNN: General Regression Neural Network for the Statistical Software R. Independant Scientist, Nancy, France, Software, 2013. Available online: http:/ / flow.chasset.net/r-grnn/ (accessed on 3 July 2021).

60. Specht, D.F. A general regression neural network. IEEE Trans. Neural Netw. 1991, 2, 568-576. [CrossRef] [PubMed]

61. Available online: https:/ / www.solarpowereurope.org/ (accessed on 5 July 2021).

62. Available online: https://wysokienapiecie.pl/35185-importujemy-coraz-wiecej-pradu-ratujemy-sasiadow-eksportem/ (accessed on 13 July 2021). 